\title{
THE USE OF DAIRY BY-PRODUCTS IN PREPARING PROBIOTIC FERMENTED MILK DRINK FORTIFIED WITH CHICKPEA
}

\author{
EL-NIMER, AMAL M.M., M.A. MOSTAFA and M.A. AHMED \\ Dairy Technology Department, Animal Production Research Institute, ARC, Dokki, \\ Giza, Egypt.
}

(Manuscript received 15 October 2014)

\begin{abstract}
The purpose of this study was to investigate the possibility of producing probiotic fermented milk drink from permeate which supplemented with different concentrations $0,1,2,3$ and $4 \%$ of chickpea and $4,3,2$ and $1 \%$ of skim milk powder using single culture of Bifidobacterium bifidum $1 \%$ with additives, natural strawberry pulp $20 \%$, sucrose $5 \%$ and carboxy methyl cellulose $0.1 \%$. Chemical, microbiological, sensory properties, amino acids, minerals and vitamin $\mathrm{C}$ content of the treatments were evaluated during storage at $5^{\circ} \mathrm{C}$ after 1,7 and 14 days. The results revealed that protein and ash contents of all treatments were significantly increased during storage, the $\mathrm{pH}$ values of all treatments significantly decreased, while the titratable acidity significantly increased $(P>0.01)$ with increasing the amount of chickpea up to $4 \%$ throughout storage. Bifidobacterium count of the treatments containing 3 and $4 \%$ chickpea gave the highest counts of bacteria more than $10^{6} \mathrm{cfu} / \mathrm{ml}$ and the viable count of Bifidobacteria remained relatively constant during 14 days of storage, approxmatly $10^{7} \mathrm{cfu} / \mathrm{ml}$. Treatments supplemented with strawberry pulp and $3,4 \%$ chickpea respectively led to high increase in calcium, potassium, phosphorus,iron and zn compared with other treatments. All treatments were considered acceptable. Treatment containing $95 \%$ permeate, $1 \%$ skim milk powder and $4 \%$ chickpea was the most preferable in sensory properties than others. The presence of Bifidobacterium bifidum in the produced fermented milk drink from permeate can be used as a probiotic dairy product and also, can be considered a good source of vitamin (C), essential amino acids, calcium and phosphorus.

Keywords: Permeate, Probiotic, Bifidobacterium bifidum, Skim milk powder, Fermented milk drink.
\end{abstract}

\section{INTRODUCTION}

Permeate is an important by -product produced by using ultrafiltration technique in the cheese industry which was often disposed as a waste in the past, causing high environmental contamination. It contains lactose as the major constituent in addition to water soluble vitamins and minerals. Probiotic microorganisms are one of the best choices for production fermented beverage based on permeate. 
Fermented beverages constitute an important part of the human diet because fermentation is one of the cheapest ways of preserving the food, improving its nutritional value and enhancing its sensory properties .

Probiotics are live microbial supplements which benefit the health of consumer by maintaining or improving their intestinal microbial balance. The Food and Agriculture Organization/(FAO), World Health confer a health benefit on the host Organization (WHO) defined probiotics as live microorganisms when administrated in adequate amounts. Probiotic food must contain at least $10^{7} \mathrm{cfu} / \mathrm{g}$ probiotic bacteria and should be consumed at levels higher than $100 \mathrm{gm} /$ day to have positive effects on health. Products in corporating human intestinal strains of Bifidobacteria either alone or together with their growth promating substances which were used for food infants suffering from nutritional disturbances, lactose intolerance and carcinogens (Coakley et. al., 2003).

Flavoured fermented milks are composite milk products which contain a maximum of $50 \%(\mathrm{w} / \mathrm{w})$ of non-dairy ingredients (such as nutritive and non nutritive sweeteners, fruits and vegetables as well as juices, purees, pulps, preparations and preserves derived there form, cereals, hony, chocolate, nuts, coffee, spices and other harmless natural flavouring foods or flavours. The non-dairy ingrdients can be mixed in prior to /or after fermentation (Codex standard 243-2003, Revision 2008).

Pulses ingredients are the dry seeds of low fat legumes including bean,pea, lentil and chickpea (Cicerarietinum). They are highly nutritional and better suppliers of minerals, particulary (potassium, calcium, phosphours, iron and zinc), essential amino acid (lysine, leucin and arginine), carbohydrates, vitamins, fiber and only very small amounts of unsaturated fats.

Various researchs have suggested that dietary intake of chickpea may reduce the risk of obesity, diabetes, heart disease and cancer.

The deficiency of certain essential amino acids in legume protein (pulse ingredients) must be supplemented with other vegetables, meat and dairy products (e.g. Whey, Yoghurt).

Accordingly, the objective of this study was using permeate which, supplemented with skim milk powder, chickpea and probiotic of Bifidobacterium bifidum culture to prepare flavoured fermented milk drink, to increase its therapeutic and nutritional value.

\section{MATERIALS AND METHODS}

\section{Materials}

\section{Permeate:}

Buffalo's milk permeate was obtained from the unit of milk processing, Animal production Research Institute, Agricultural Research Center, Giza, Egypt. The chemical 
composition of permeat was, moisture $(94 \%)$, lactose $(5.0 \%)$, protein $(0.24 \%)$, ash $(0.54 \%)$ and $\mathrm{pH}$ value (6.45).

\section{Chickpea:}

The chickpea seeds were obtained from the local market.The seeds were cleaned manually, washed to be free of dust and foreign materials, then stored in polyethylene bags at $-5^{\circ} \mathrm{C}$ until used. It contains $25.0 \%$ protein, $6.63 \%$ fat, $3.76 \%$ crude fiber, $60.4 \%$ total carbohydrate and $1.2 \%$ ash.

\section{Skim milk powder (S.M.P.) :}

It was obtained from the local market.It contains $3.4 \%$ moisture, $1.25 \%$ fat, $34 \%$ protein, $50 \%$ lactose and $7.5 \%$ ash.

\section{Carboxy methyl cellulose (CMC) :}

It was obtained from Danisso Ingredients (Copenhagen,Denmark) and used as a stabilizer.

Strawberry (Sweet sharpley) and sugar (sucrose) were purchased from the local market.

\section{Culture and media for microbiological analysis:}

Bifidobacterium bifidum Bb-12 was obtained from Chr. Hansen Lab.Copenhagen, Denmark. Bifidobacteria was activated in modified MRS broth (Difco Laboratories, Detroit, Michigan, USA) which was prepared according to Ventling and Mistry (1993). Microbiological media was obtained from Oxoid Division of Oxiod Ltd, London.

\section{- Preparation of chickpea:}

The chickpea was soaked in water for 8 hrs and then blanched in boiling tap water for $15 \mathrm{~min}$, then cooled by tap water and dehulled. The dehulled seeds were dried at $60^{\circ} \mathrm{C}$ for $12 \mathrm{hrs}$, then grinded.

\section{- Prepation of strawberry juice:}

Fresh strawberries were cleaned, washed and then blended and filtereds to remove the seeds, then heated at $85^{\circ} \mathrm{C} / 5 \mathrm{~min}$,cooled to $20^{\circ} \mathrm{C}$, packed in polyethylene pouches and was kept frozen until used.

\section{- Preparation of probiotic fermented milk drink:}

\section{Probiotic fermented milk drink was prepared as follows:}

Permeate was added to skim milk powder (SMP) by the ratio (95: $5 \%$ ) then $5 \%$ sugar ,20\% strawberry juice and $0.1 \%$ carboxy methyl cellulose were added (control $\mathbf{T}_{\mathbf{1}}$ ) and then chickpea was added in the other treatments from the percentage of skim milk powder, $\mathbf{T}_{\mathbf{2}}: 4 \% \mathrm{SMP}+1 \%$ chickpea, $\mathbf{T}_{\mathbf{3}}: 3 \% \mathrm{SMP}+2 \%$ chickpea, $\mathbf{T}_{\mathbf{4}}: 2 \%$ SMP+3\% chickpea, $\mathbf{T}_{\mathbf{5}}: 1 \%$ SMP+4\% chickpea(Table,1).The whole mixture was blended and filtered. Prepared mixture was heated $a t 75^{\circ} \mathrm{c} / 10 \mathrm{sec}$., 
rapidly cooled to $40^{\circ} \mathrm{C}$, divided into 5 equal portions and each $\mathbf{T}_{\mathbf{3}}$ portion was put in a flask then inoculated by $1 \%$ of Bifidobacterium bifidum $\mathrm{Bb}-12$, and finally incubated at $37^{\circ} \mathrm{C}$ for $48 \mathrm{hrs}$.

Table 1 . The ingredient of the prepared probiotic fermented milk drink. $(\mathrm{kg})$

\begin{tabular}{|c|c|c|c|c|c|c|c|}
\hline $\begin{array}{c}\text { Number of } \\
\text { samples }\end{array}$ & $\begin{array}{c}\text { Permeate } \\
\%\end{array}$ & $\begin{array}{c}\text { Skim milk } \\
\text { powder \% }\end{array}$ & $\begin{array}{c}\text { Chick pea } \\
\%\end{array}$ & $\begin{array}{c}\text { Straw } \\
\text { berry } \\
\text { juice } \%\end{array}$ & $\begin{array}{c}\text { Bifido } \\
\text { bacterium } \\
\%\end{array}$ & $\begin{array}{c}\text { Sucros } \\
\mathbf{e} \%\end{array}$ & $\begin{array}{c}\text { CMC } \\
\%\end{array}$ \\
\hline Control ( $\left.\mathbf{T}_{\mathbf{1}}\right)$ & 95 & 5 & 0 & 20 & 1 & 5 & 0.1 \\
\hline $\mathbf{T}_{\mathbf{2}}$ & 95 & 4 & 1 & 20 & 1 & 5 & 0.1 \\
\hline $\mathbf{T}_{\mathbf{3}}$ & 95 & 3 & 2 & 20 & 1 & 5 & 0.1 \\
\hline $\mathbf{T}_{\mathbf{4}}$ & 95 & 2 & 3 & 20 & 1 & 5 & 0.1 \\
\hline $\mathbf{T}_{\mathbf{5}}$ & 95 & 1 & 4 & 20 & 1 & 5 & 0.1 \\
\hline
\end{tabular}

Treatments: $T_{1}$ (control)= probiotic fermented milk drink made from $95 \%$ of permeate, $5 \%$ skim milk powder $+5 \%$ sucrose $+20 \%$ strawberry pulp $+0.1 \%$ CMC $+1 \%$ Bifidobacterium.

The chemical composition of the rgrechant used in prepareding fermented milk drink is presented in Table (2). The treatments were stored at $5^{\circ} \mathrm{C}$ and evaluated after 1,7 and 14 days for sensory evaluation, $\mathrm{pH}$, viscosity viscometer, microbiological properties (total counts of the viable Bifidobacterium bifidum), minerals content (calcium, potassium, phosphorus, zinc and iron), essential amino acids and vitamin C.

Table 2. Chemical composition of the ingredients used preparing probiotic fermented milk drink.

\begin{tabular}{|l|c|c|c|c|}
\hline \multicolumn{1}{|c|}{ Component } & Permeate & $\begin{array}{c}\text { Skim milk } \\
\text { powder }\end{array}$ & Chickpea & $\begin{array}{c}\text { Strawberry } \\
\text { juice }\end{array}$ \\
\hline Protein \% & 0.24 & 34 & 25.00 & 1.94 \\
\hline Fat \% & 0.1 & 1.25 & 6.63 & - \\
\hline Lactose \% & 5.0 & 50 & - & - \\
\hline Ash \% & 0.54 & 7.5 & 1.2 & 0.34 \\
\hline Fibers \% & - & - & 3.76 & 0.38 \\
\hline Total \% sucrose & - & - & - & 5.10 \\
\hline Total \% carbohydrate & - & - & 60.4 & - \\
\hline
\end{tabular}

\section{Method of analysis:}

\section{Chemical analysis:}

The $\mathrm{pH}$ of fermented milk drink samples was determined using a digital $\mathrm{pH}$ meter (M41150, USA) equipped with glass electrodes. The acidity \%, total protein \%, total solid\% fat content $\%$ and ash were determined according to A.O.A.C. (2002). 
Lactose was determined calorimetrically according to (Bernett and Abd El-Tawab 1957) using spectrophotometer at $490 \mathrm{~nm}$ wave length type Shimadzu UV 240.

Minerals content: were determined using Advanced Microwave Digestion System Atomic Emission Spectometry ETHOSI. Sample were measured by using Inductively Coupled plasma (ICP-AES), Thermo Sci, model: ICAP 6000 series. Phosphorus content was determined as molybdenum blue by the colorimetric method of Allen (1940).

Amino acids analysis were measured according to the method of Block et. al., (1958). by using Amino Acid Analyzer, A.A.A. 400.

Vitamin C: was determined according to method of National Food Agency of Denmark, Ministry of Health, Institute Food Chemistry and Nutrition Danish Official (1996).

\section{Viscosity:}

The viscosity of fermented milk drink was determined by using Brook field DV II + Viscometer with a T-C spindle that rotated at $10 \mathrm{rpm}$. One hundred data points were averaged per replication.

\section{Microbiological properties:}

Treatments were analysed at 1,7 and 14 days of storage for enumeration of Bifidobacterium as described by Dave \& Shah (1996) using MRS Agar medium supplemented with $0.05 \% \mathrm{~L}$ - cysteine. $\mathrm{HCl}$ (plates were incubated in an anaerobic environment at $37^{\circ} \mathrm{C} / 48 \mathrm{~h}$. The result expressed as $\log _{10}$ colony forming unit (cfu)/ml of sample.

\section{Sensory evaluation:}

The sensory evaluation was done according to Farag et. al., (1993) by 15 panalist from the staff members of Dairy technology , Department, Animal production Research Institute (APRI). Samples were scored for flavor of (50 points), color (10 points), appearance (lo points) and consistency (30 points).

\section{Statistical Analysis:}

Complete Randumze Block Design method was for the statistical analysis Duncan multiple range test (1955) was used to test the significance between means. Trials of each treatments were of three replicates.

\section{RESULTS AND DISCUSSION}

\section{Chemical composition:}

Chemical composition of probiotic fermented milk drink is presented in Table (3). It is clear that total solids (TS) content of control $\left(T_{1}\right)$ and treatments 
supplemented with 1,2,3 and 4\% chickpea (T2,T3,T4 and T5) during storage ranged from 13.65 to $14.10 \%$ in control and 14.11 to $14.69 \%$ in the other treatments respectively. These results mainly due to the addition of skim milk powder, fruit juice, sugar and chickpea to the pre-treated permeate.

Concerning, the fat content of all probiotic fermented milk drinks were slightly increased from 0.35 to $0.69 \%$ throughout the storage periods. Similar results were reported by Hegazi et. al., (2009) who used milk permeate in making fruit beverages and stored the products for 30 days.

Table 3. Total solids and fat content of probiotic fermented milk drink during storage for 1,7 and 14 days at $5^{\circ} \mathrm{C}$.

\begin{tabular}{|c|c|c|c|c|}
\hline \multirow{2}{*}{ Treatments } & \multicolumn{4}{|c|}{ Storage period (days) } \\
\cline { 2 - 5 } & $\mathbf{1}$ & $\mathbf{7}$ & $\mathbf{1 4}$ & 土 SE \\
\cline { 2 - 5 } & \multicolumn{4}{|c|}{ Total solids \% } \\
\hline $\mathbf{T}_{\mathbf{1}}$ (control) & $13.65^{\mathrm{i}}$ & $14.00^{\mathrm{h}}$ & $14.10^{\mathrm{g}}$ & 0.70 \\
\hline $\mathbf{T}_{\mathbf{2}}$ & $14.11^{\mathrm{g}}$ & $14.18^{\mathrm{f}}$ & $14.25^{\mathrm{ef}}$ & 0.70 \\
\hline $\mathbf{T}_{\mathbf{3}}$ & $14.30^{\mathrm{e}}$ & $14.39^{\mathrm{de}}$ & $14.44^{\mathrm{d}}$ & 0.70 \\
\hline $\mathbf{T}_{\mathbf{4}}$ & $14.47^{\mathrm{cd}}$ & $14.51^{\mathrm{c}}$ & $14.57^{\mathrm{bc}}$ & 0.70 \\
\hline $\mathbf{T}_{\mathbf{5}}$ & $14.59^{\mathrm{b}}$ & $14.64^{\mathrm{ab}}$ & $14.69^{\mathrm{a}}$ & 0.70 \\
\hline & & \multicolumn{5}{|c|}{ Fat content \% } & \\
\hline $\mathbf{T}_{\mathbf{1}}$ & 0.35 & 0.41 & $0.44^{\mathrm{c}}$ & 0.25 \\
\hline $\mathbf{T}_{\mathbf{2}}$ & 0.47 & 0.53 & $0.55^{\mathrm{b}}$ & 0.25 \\
\hline $\mathbf{T}_{\mathbf{3}}$ & 0.47 & 0.53 & $0.55^{\mathrm{b}}$ & 0.25 \\
\hline $\mathbf{T}_{\mathbf{4}}$ & 0.48 & 0.64 & $0.67^{\mathrm{ab}}$ & 0.25 \\
\hline $\mathbf{T}_{\mathbf{5}}$ & 0.49 & 0.67 & $0.69^{\mathrm{a}}$ & 0.25 \\
\hline
\end{tabular}

$a, b, \ldots$. etc means with different superscripts in the same row or column within different significantly $(\mathrm{P}<0.05)$.

Supplementation of permeate with skim milk powder and chickpea significantly increased the protein, and ash contents of the probiotic fermented milk drinks (Table 4). Protein and ash contents ranged from 4.88 to $5.93 \%$ and 1.1 to $1.35 \%$ respevtively for fresh samples.

During storage, Both of protein, and ash contents of all treatments were significantly increased, ranged from 4.99 to $6.44 \%$ and 1.13 to $1.75 \%$ respectively.

The apparent increase of protein and ash contents are due to the increase in total solids because of high dry agent content of used fruit juice. Conversely, for all treatments as the storage period progressed the lactose content gradually decreased due to the hydrolysis of lactose. These results are in agreement with those reported by (Tonguc,2012). 
Table 4.Total protein, lactose and ash contents of probiotic fermented milk drink during storage for 1,7 and 14 days at $5^{\circ} \mathrm{C}$.

\begin{tabular}{|c|c|c|c|c|}
\hline \multirow{3}{*}{ Treatments } & \multicolumn{4}{|c|}{ Storage period (days) } \\
\hline & 1 & 7 & 14 & \pm SE \\
\hline & \multicolumn{4}{|c|}{ Protein \% } \\
\hline $\mathbf{T}_{1}$ & $4.88^{\mathrm{eg}}$ & $4.99^{\mathrm{e}}$ & $6.05^{\mathrm{ed}}$ & 0.40 \\
\hline $\mathbf{T}_{2}$ & $5.44^{\mathrm{ef}}$ & $5.69^{\mathrm{e}}$ & $6.12^{\mathrm{bc}}$ & 0.40 \\
\hline $\mathbf{T}_{3}$ & $5.84^{\text {de }}$ & $5.91^{\mathrm{d}}$ & $6.23^{b}$ & 0.40 \\
\hline $\mathbf{T}_{4}$ & $5.91^{\mathrm{d}}$ & $5.99^{\text {cd }}$ & $6.35^{\mathrm{ab}}$ & 0.40 \\
\hline \multirow[t]{2}{*}{$T_{5}$} & $5.93^{d}$ & $6.1^{\mathrm{c}}$ & $6.44^{\mathrm{a}}$ & 0.40 \\
\hline & \multicolumn{4}{|c|}{ Lactose $\%$} \\
\hline $\mathbf{T}_{1}$ & $4.24^{\mathrm{a}}$ & $4.19^{b}$ & $4.08^{\mathrm{de}}$ & 0.30 \\
\hline $\mathbf{T}_{2}$ & $4.24^{\mathrm{a}}$ & $4.17^{\mathrm{bc}}$ & $4.06^{\mathrm{e}}$ & 0.30 \\
\hline $\mathbf{T}_{3}$ & $4.25^{\mathrm{a}}$ & $4.18^{\mathrm{bc}}$ & $4.09^{d}$ & 0.30 \\
\hline $\mathbf{T}_{4}$ & $4.25^{\mathrm{a}}$ & $4.18^{\mathrm{bc}}$ & $4.08^{\mathrm{de}}$ & 0.30 \\
\hline \multirow[t]{2}{*}{$T_{5}$} & $4.25^{\mathrm{a}}$ & $4.20^{\mathrm{b}}$ & $4.11^{\mathrm{C}}$ & 0.30 \\
\hline & \multicolumn{4}{|c|}{ Ash\% } \\
\hline $\mathbf{T}_{\mathbf{1}}$ & $1.1^{\mathrm{ef}}$ & $1.13^{\mathrm{e}}$ & $1.37^{\mathrm{cd}}$ & 0.06 \\
\hline $\mathbf{T}_{2}$ & $1.15^{\mathrm{e}}$ & $1.20^{\text {de }}$ & $1.45^{\mathrm{e}}$ & 0.06 \\
\hline $\mathbf{T}_{3}$ & $1.30^{\mathrm{d}}$ & $1.37^{\text {cd }}$ & $1.57^{\mathrm{b}}$ & 0.06 \\
\hline $\mathbf{T}_{4}$ & $1.34^{\text {cd }}$ & $1.45^{c}$ & $1.63^{\mathrm{ab}}$ & 0.06 \\
\hline $\mathbf{T}_{5}$ & $1.35^{\mathrm{cd}}$ & $1.52^{\mathrm{bc}}$ & $1.75^{\mathrm{a}}$ & 0.06 \\
\hline
\end{tabular}

$a, b, \ldots$ etc means with different superscripts in the same row or column within different significantly $(P<0.05)$.

Data presented in Table (5) revealed that the $\mathrm{pH}$ values of the probiotic fermented milk drink made from $95 \%$ of permeate: $5 \%$ skim milk powder supplemented with $0,1,2,3$ and $4 \%$ chickpea respecetively (T1,T2,T3,T4andT5), were ranged $4.76,4.75,4.67,4.65$ and 4.60 at the first day of storage. $\mathrm{pH}$ values of all treatments were slightly insignificant decrease on 7 and 14 days of storage.The decrease in $\mathrm{pH}$ values were the same during fermentation and storage in all treatments. These addition had negligible influence on the dynamics of $\mathrm{pH}$ decreased. These decrease in $\mathrm{pH}$ values agreed with data obtained by Hegazi et. al., (2009).Titratable acidity of treatments ranged from 0.55 to 0.85 on the first day and these values of all treatments were insignificant during storage.These results are in agreement with those obtained by Abd El_Salam et. al., (2007) when prepared a functional beverage from permeate and tomato syrup. 
Table 5. Titratable acidity and $\mathrm{pH}$ values of probiotic fermented milk drink during storage for 1,7 and 14 days at $5^{\circ} \mathrm{C}$.

\begin{tabular}{|c|c|c|c|c|}
\hline \multirow{2}{*}{ Treatments } & \multicolumn{4}{|c|}{ Storage period (days) } \\
\cline { 2 - 5 } & $\mathbf{1}$ & $\mathbf{7}$ & $\mathbf{1 4}$ & 土 SE \\
\cline { 2 - 5 } & \multicolumn{4}{|c|}{ Acidity \% } \\
\hline $\mathbf{T}_{\mathbf{1}}$ & $0.55^{\mathrm{g}}$ & $0.60^{\mathrm{fg}}$ & $0.63^{\mathrm{f}}$ & 0.065 \\
\hline $\mathbf{T}_{\mathbf{2}}$ & $0.63^{\mathrm{f}}$ & $0.69^{\mathrm{e}}$ & $0.74^{\mathrm{d}}$ & 0.065 \\
\hline $\mathbf{T}_{\mathbf{3}}$ & $0.66^{\mathrm{ef}}$ & $0.74^{\mathrm{d}}$ & $0.85^{\mathrm{c}}$ & 0.065 \\
\hline $\mathbf{T}_{\mathbf{4}}$ & $0.80^{\mathrm{cd}}$ & $0.89^{\mathrm{bc}}$ & $0.98^{\mathrm{a}}$ & 0.065 \\
\hline $\mathbf{T}_{\mathbf{5}}$ & $0.85^{\mathrm{c}}$ & $0.92^{\mathrm{b}}$ & $0.98^{\mathrm{a}}$ & 0.065 \\
\hline $\mathbf{T}_{\mathbf{1}}$ & & \multicolumn{1}{|c|}{$\mathbf{p H}$ values } \\
\hline $\mathbf{T}_{\mathbf{2}}$ & $4.76^{\mathrm{a}}$ & $4.73^{\mathrm{ab}}$ & $4.67^{\mathrm{bc}}$ & 0.016 \\
\hline $\mathbf{T}_{\mathbf{3}}$ & $4.75^{\mathrm{a}}$ & $4.71^{\mathrm{b}}$ & $4.70^{\mathrm{b}}$ & 0.016 \\
\hline $\mathbf{T}_{\mathbf{4}}$ & $4.67^{\mathrm{bc}}$ & $4.65^{\mathrm{c}}$ & $4.62^{\mathrm{d}}$ & 0.016 \\
\hline $\mathbf{T}_{\mathbf{5}}$ & $4.65^{\mathrm{c}}$ & $4.60^{\mathrm{de}}$ & $4.58^{\mathrm{e}}$ & 0.016 \\
\hline & $4.60^{\mathrm{de}}$ & $4.56^{\mathrm{ef}}$ & $4.53^{\mathrm{f}}$ & 0.016 \\
\hline
\end{tabular}

$a, b, \ldots$. etc means with different superscripts in the same row or column within different significantly $(\mathrm{P}<0.05)$.

Some minerals contents of prepared fermented milk drink are illustrated in (Table 6).The obtained results revealed that significant higher contents of calcium, potassium, phosphorus, iron and zinc during storage period progressed of fermented milk drink treatments with chickpea compared with control. Generally recorded value for $\mathrm{Ca}, \mathrm{K}, \mathrm{P}, \mathrm{Fe}$ were $35.8,59.4,40,4.3 \mathrm{mg} / 100 \mathrm{~g}$ and zn wase $46 \mathrm{ppb}$ respectively after 1 day for control treatment $\left(T_{1}\right)$. Adding chick pea at different ratio significantly $(P<0.05)$ increased the minerals content of the treatments $\left(T_{2}-T_{5}\right)$ after 1 day ranged from 37.11:47.00, 63.8:110.3, 62:82, 4.9:11.3 mg/ 100g and 61:133 ppb for Ca, $\mathrm{K}, \mathrm{P}$, Fe and $\mathrm{Zn}$ respectively.

During storage for 14 days, iy was observed that minerals contents in both control and other treatments $\left(T_{1}: T_{5}\right)$ are significantly increased $(P<0.05)$ from 37.00:51.02, 65.3-116.5, 42-102, 5.2-16.4 mg/100g and 49-152ppb for $\mathrm{Ca}, \mathrm{K}, \mathrm{P}$, Fe and $\mathrm{Zn}$ respectively (Table, 8). These results are in agreement with Zare et. al., (2009) who used pulse ingredients (chick pea flour) in the development of orange juice and apple juice supplemented beverages and stored the products for 4 weeks. They found that,chick pea and strawberry could serve as the higher content of minerals. 
Table 6. Minerals content $(\mathrm{mg} / 100 \mathrm{~g})$ of probiotic fermented milk drink during storage for 1 and 14 days at $5^{\circ} \mathrm{C}$.

\begin{tabular}{|c|c|c|c|c|c|c|}
\hline \multirow[b]{2}{*}{ Treatments } & \multirow[b]{2}{*}{$\begin{array}{c}\text { Storage period } \\
\text { (days) }\end{array}$} & \multicolumn{5}{|c|}{ Minerals content } \\
\hline & & $\begin{array}{c}\mathrm{Ca} \\
\mathrm{mg} / 100 \\
\mathrm{~g}\end{array}$ & $\begin{array}{c}\mathrm{K} \\
\mathrm{mg} / / \mathbf{1 0} \\
\mathbf{0 g}\end{array}$ & $\begin{array}{c}P \\
\mathrm{mg} / 10 \\
0 \mathrm{~g}\end{array}$ & $\begin{array}{c}\mathrm{Fe} \\
\mathrm{mg} / 100 \\
\mathrm{~g}\end{array}$ & $\begin{array}{c}\text { Zn } \\
\text { Ppb/100 } \\
\text { g }\end{array}$ \\
\hline $\mathbf{T}_{1}$ & $\begin{array}{l}1 \text { day } \\
14 \text { day }\end{array}$ & $\begin{array}{l}35.8^{\mathrm{d}} \\
37.00^{\mathrm{e}}\end{array}$ & $\begin{array}{l}59.4^{\mathrm{cd}} \\
65.3^{\mathrm{c}}\end{array}$ & $\begin{array}{l}40^{d} \\
42^{c}\end{array}$ & $\begin{array}{l}4.3^{b c} \\
5.2^{c}\end{array}$ & $\begin{array}{l}46^{e} \\
49^{d}\end{array}$ \\
\hline $\mathbf{T}_{2}$ & $\begin{array}{l}1 \text { day } \\
14 \text { day }\end{array}$ & $\begin{array}{l}37.11^{\mathrm{cd}} \\
40.02^{\mathrm{d}}\end{array}$ & $\begin{array}{l}63.8^{\mathrm{c}} \\
82.0^{\mathrm{bc}}\end{array}$ & $\begin{array}{l}62^{\mathrm{c}} \\
87^{\mathrm{bc}}\end{array}$ & $\begin{array}{l}4.9^{b} \\
5.3^{c}\end{array}$ & $\begin{array}{l}61^{\mathrm{d}} \\
71^{\mathrm{c}}\end{array}$ \\
\hline$T_{3}$ & $\begin{array}{l}1 \text { day } \\
14 \text { day }\end{array}$ & $\begin{array}{l}41.11^{c} \\
43.10^{c}\end{array}$ & $\begin{array}{l}76.0^{\mathrm{bc}} \\
87.2^{\mathrm{b}}\end{array}$ & $\begin{array}{l}71^{\mathrm{b}} \\
92^{\mathrm{b}}\end{array}$ & $\begin{array}{l}10.0^{\mathrm{ab}} \\
12.6^{\mathrm{b}}\end{array}$ & $\begin{array}{l}90^{c} \\
71^{c}\end{array}$ \\
\hline $\mathbf{T}_{4}$ & $\begin{array}{c}1 \text { day } \\
14 \text { day }\end{array}$ & $\begin{array}{c}42.2^{\mathrm{b}} \\
46.17^{\mathrm{b}}\end{array}$ & $\begin{array}{c}77.4^{\mathrm{b}} \\
100.0^{\mathrm{ab}}\end{array}$ & $\begin{array}{l}77^{\mathrm{ab}} \\
97^{\mathrm{ab}}\end{array}$ & $\begin{array}{l}10.8^{\mathrm{ab}} \\
15.9^{\mathrm{ab}}\end{array}$ & $\begin{array}{l}123^{\mathrm{b}} \\
101^{\mathrm{b}}\end{array}$ \\
\hline$T_{5}$ & $\begin{array}{l}1 \text { day } \\
14 \text { day }\end{array}$ & $\begin{array}{l}47.00^{\mathrm{a}} \\
51.02^{\mathrm{a}}\end{array}$ & $\begin{array}{l}110.3^{\mathrm{a}} \\
116.5^{\mathrm{a}}\end{array}$ & $\begin{array}{c}82^{\mathrm{a}} \\
102^{\mathrm{a}}\end{array}$ & $\begin{array}{l}11.3^{\mathrm{a}} \\
16.4^{\mathrm{a}}\end{array}$ & $\begin{array}{l}133^{\mathrm{a}} \\
152^{\mathrm{a}}\end{array}$ \\
\hline
\end{tabular}

$a, b, \ldots$. etc means with different superscripts in the same row or column within different significantly $(P<0.05)$.

Amino acids content of prepared probiotic fermented milk drink are presented in (Table, 7), obtained results clearly show, that probiotic fermented milk drink containing 3 and $4 \%$ chickpea $\left(T_{4}\right.$ and $T_{5}$ ) had higher contents of amino acids compared with control (T1) and treatments containing 1 and 2\% chickpea (T2 and T3) respectively. This finding can be attributed to the higher content of total protein in chickpea and skim milk powder.The obtained results are in line with those found by Katsanos, et. al., (2006). 
Table 7. Amino acids content of fresh probiotic fermented milk drink.

\begin{tabular}{|c|c|c|c|c|c|}
\hline \multirow{2}{*}{ Amino acids\% } & \multicolumn{5}{|c|}{ Treatments } \\
\cline { 2 - 6 } & Control $\left(\mathbf{T}_{\mathbf{1}}\right)$ & $\mathbf{T}_{\mathbf{2}}$ & $\mathbf{T}_{\mathbf{3}}$ & $\mathbf{T}_{\mathbf{4}}$ & $\mathbf{T}_{\mathbf{5}}$ \\
\hline ASP & 5.36 & 8.13 & 8.23 & 9.55 & 10.30 \\
\hline Ser & 1.54 & 1.59 & 1.67 & 1.87 & 2.01 \\
\hline Glu & 3.48 & 3.51 & 3.85 & 4.15 & 5.01 \\
\hline Pro & 16.57 & 17.57 & 18.25 & 18.70 & 19.20 \\
\hline Gly & 0.11 & 0.33 & 0.35 & 0.42 & 0.59 \\
\hline Ala & 4.07 & 4.09 & 5.12 & 5.56 & 6.12 \\
\hline Val & 5.02 & 6.36 & 6.40 & 6.59 & 7.62 \\
\hline Leu & 7.61 & 5.66 & 5.85 & 6.11 & 7.11 \\
\hline Isoleu & 3.38 & 8.32 & 8.50 & 8.69 & 9.12 \\
\hline Tyr & 1.87 & 2.62 & 3.88 & 4.04 & 5.47 \\
\hline His & 1.55 & 1.83 & 1.89 & 1.96 & 2.27 \\
\hline Lys & 6.52 & 6.56 & 6.59 & 6.65 & 6.75 \\
\hline Arg & 2.31 & 2.55 & 2.65 & 3.67 & 4.92 \\
\hline Phe & 1.70 & 1.80 & 1.88 & 2.07 & 2.13 \\
\hline
\end{tabular}

Averaged data for three samples of fermented milk analysed in duplicate.

Table (8) shows content of vitamin $\mathrm{C}$ in the treatments of probiotic fermented milk drink supplemented with natural strawberry juice at the rate of $20 \%$ and chickpea at different ratio 1, 2, 3 and $4 \%$. Addition of chickpea increase the vitamin C from $0.38 \mathrm{mg} / 100 \mathrm{gm}$ in control $\left(T_{1}\right)$ sample of probiotic fermented milk drink to reach $0.49,0.55,0.70$ and $0.78 \mathrm{mg} / 100 \mathrm{gm}$ in the treatments supplemented with 2, 3 and $4 \%$ chickpea $\left(T 2, T_{3}, T_{4}\right.$ and $\left.T_{5}\right)$ respectively. This results showed that permeate is a good source of lactose (milk sugar), minerals such as calcium, potassium, sodium and phosphorus and water soluble vitamins such as vitamin $\mathrm{C}$. In the same line, this results in agreement with the results obtained by Abd El-Khair, 2009.

Table 8. Vitamin C content ( $\mathrm{mg} / 100 \mathrm{gm})$ of fresh probiotic fermented milk drink.

\begin{tabular}{|c|c|}
\hline Treatments & The content of vitamin $\mathbf{C ~} \mathbf{~ g} / \mathbf{1 0 0 g m}$ \\
\hline Control $\mathbf{T}_{\mathbf{1}}$ & 0.38 \\
\hline $\mathbf{T}_{\mathbf{2}}$ & 0.49 \\
\hline $\mathbf{T}_{\mathbf{3}}$ & 0.55 \\
\hline $\mathbf{T}_{\mathbf{4}}$ & 0.70 \\
\hline $\mathbf{T}_{\mathbf{5}}$ & 0.78 \\
\hline
\end{tabular}


Addition of chickpea, probiotic culture (Bifidobacteirum bifidum Bb-12) and natural fruit (strawberry) to the mixture of permeate and skim milk powder on the viscosity is presented in (Table 9).

It is clear from the data obtained that the viscosity values increased as the chickpea percent increased of fermented milk drink during storage. The viscosity values for control sample $\left(T_{1}\right)$ after 1 day and during storage ranged from 404.4 to 564.8 centipoises (cp). In the same line, addition of $1,2,3$ and $4 \%$ chickpea led to significant increase of the viscosity values from 430.6 to $495.3 \mathrm{cp}$ for $T_{2}$ until $T_{5}$ samples respectively when fresh (after 1 day), (Table 9).

Storing fermented milk drink for 7 and 14 days led to significant increase of the viscosity values of all samples from $T_{2}$ to $T_{5}$. This increase in the viscosity may be reffered to increasing of acidity, protein ratio and to the stabilizer action These results are in agreement with those reported by Folkenberg et. al., (2006), they found that some strains of lactic acid bacteria used in the manufacture of fermented milks produced expolysaccharides, that increased the viscosity of fermented milks and improved the physical properties during storage.

Table 9. Viscosity of probiotic fermented milk drink during storage for 1,7 and 14 days at $5^{\circ} \mathrm{C}$.

\begin{tabular}{|c|c|c|c|c|}
\hline \multirow{2}{*}{ Treatments } & \multicolumn{4}{|c|}{ Storage period (days) } \\
\cline { 2 - 5 } & $\mathbf{1}$ & $\mathbf{7}$ & $\mathbf{1 4}$ & 土 SE \\
\cline { 2 - 5 } & \multicolumn{4}{|c|}{ Viscosity cp. } \\
\hline $\mathbf{T}_{\mathbf{1}}$ & $404.4^{\mathrm{i}}$ & $518.1^{\mathrm{f}}$ & $564.8^{\mathrm{d}}$ & 2.01 \\
\hline $\mathbf{T}_{\mathbf{2}}$ & $430.6^{\mathrm{hi}}$ & $540.0^{\mathrm{e}}$ & $585.00^{\mathrm{c}}$ & 2.01 \\
\hline $\mathbf{T}_{\mathbf{3}}$ & $456.0^{\mathrm{h}}$ & $554.0^{\mathrm{de}}$ & $596.00^{\mathrm{bc}}$ & 2.01 \\
\hline $\mathbf{T}_{\mathbf{4}}$ & $479.7^{\mathrm{g}}$ & $596.0^{\mathrm{bc}}$ & $620.0^{\mathrm{abb}}$ & 2.01 \\
\hline $\mathbf{T}_{\mathbf{5}}$ & $495.3^{\mathrm{fg}}$ & $616.0^{\mathrm{b}}$ & $642.00^{\mathrm{a}}$ & 2.01 \\
\hline
\end{tabular}

$a, b, \ldots$. etc means with different superscripts in the same row or column within different significantly $(P<0.05)$.

Data illustrated in $(T a b l e, 10)$ revealed that adding chickpea and skim milk powder to permeate led to significant increase in log $\mathrm{cfu} / \mathrm{ml}$ on MRS-Agar medium supplemented with $0.05 \mathrm{~L}$-cystein. $\mathrm{HCL}$ (count of Bifidobacterium bifidum).

A significant increase $(P>0.01)$ was clear in the viable Bifidobacterium bifidum of probiotic fermented milk drink in all treatments during storage period at $5^{\circ} \mathrm{C}$ (Table,10). The samples supplemented with 3 and $4 \%$ chickpea had high Bifidobacteiral counts more than log $\left(\mathrm{cfu} / \mathrm{ml} 10^{6}\right)$ of living bacteria and the viable count of B.bifidum remained approximatly constant during the 14 days of storage at $5^{\circ} \mathrm{C}$ (approximatly $10^{7} \mathrm{cfu} / \mathrm{ml}$ ). This results showed that permeate was suitable for this 
intestinal bacteria, that was kept viable during storage (14 days). These results were agreed with Aumara and Hassan (2007) when prepared a fermented milk from doum palm fruit powder.They found that the minimum required level of probiotic bacteria to be useful for the consumer body is $10^{7} \mathrm{cfu} / \mathrm{ml}$ of living bacteria.

Table 10. Total bacterial count of the viable Bifidobacterium bifidum $\left(\log _{10} / \mathrm{ml}\right)$ of probiotic fermented milk drink during storage for 1,7 and 14 days at $5^{\circ} \mathrm{C}$.

\begin{tabular}{|c|c|c|c|c|}
\hline \multirow{2}{*}{ Treatments } & \multicolumn{4}{|c|}{ Storage period (days) } \\
\cline { 2 - 5 } & $\mathbf{1}$ & $\mathbf{7}$ & $\mathbf{1 4}$ & \pm SE \\
\cline { 2 - 5 } & \multicolumn{4}{|c|}{ Viable of Bifidobacterial counts } \\
\hline $\mathbf{T}_{\mathbf{1}}$ & $12 \times 10^{6}$ & $185 \times 10^{6}$ & $185 \times 10^{6}$ & 0.08 \\
\hline $\mathbf{T}_{\mathbf{2}}$ & $15 \times 10^{6}$ & $192 \times 10^{6}$ & $192 \times 10^{6}$ & 0.08 \\
\hline $\mathbf{T}_{\mathbf{3}}$ & $33 \times 10^{6}$ & $40 \times 10^{7}$ & $44 \times 10^{7}$ & 0.08 \\
\hline $\mathbf{T}_{\mathbf{4}}$ & $50 \times 10^{6}$ & $44 \times 10^{7}$ & $49 \times 10^{7}$ & 0.08 \\
\hline $\mathbf{T}_{\mathbf{5}}$ & $55 \times 10^{6}$ & $52 \times 10^{7}$ & $55 \times 10^{7}$ & 0.08 \\
\hline
\end{tabular}

$a, b, \ldots$. etc means with different superscripts in the same row or column within different significantly $(P<0.05)$.

The sensory evaluation of prepared fresh and during storage period of fermented milk drink at $5^{\circ} \mathrm{C}$ are presented in (Table,11). There was a significant differences $(P>0.01)$ between the control $\left(T_{1}\right)$ and other treatments supplemented with different rates of 1, 2, 3 and 4\% chickpea in all parameters (color, appearance, flavour and consistency) after 1day and during storage at $5^{\circ} \mathrm{C}$.

The sensory score for control sample $\left(T_{1}\right)$ had lower score points for flavour, consistency, appearance and color when compared with other treatments (Table 11).

The scores begin to decrease graduall in all fermented drink until they gained the lowest values at the end of storage period. This decrease in acceptability due to increase in viscosity and more acidic taste., a slight acidification was detected in the treatmes by the judges. They agreed that the fermented milk drink supplemented with $4 \%$ chickpea had an acceptable flavor compared with others. In related works, Davidson et. al., (2000) reported that in a fermented frozen yogurt, acidity was the most important attribute. 
Table 11. sensory evaluation of probiotic fermented milk drink during storage for 1,7 and 14 days at $5^{\circ} \mathrm{C}$.

\begin{tabular}{|c|c|c|c|}
\hline \multirow{2}{*}{ Treatments } & \multicolumn{3}{|c|}{ Storage period (days) } \\
\hline & 1 & 7 & 14 \\
\hline & \multicolumn{3}{|c|}{ Color (10) } \\
\hline $\mathbf{T}_{1}$ & $7^{b}$ & $7^{b}$ & $6^{\mathrm{b}}$ \\
\hline $\mathbf{T}_{2}$ & $8^{\mathrm{a}}$ & $8^{a}$ & $7^{b}$ \\
\hline $\mathbf{T}_{3}$ & $8^{\mathrm{a}}$ & $8^{a}$ & $7^{b}$ \\
\hline $\mathbf{T}_{4}$ & $9^{a}$ & $9^{a}$ & $8^{\mathrm{a}}$ \\
\hline \multirow[t]{2}{*}{$T_{5}$} & $9^{a}$ & $9^{a}$ & $8^{\mathrm{a}}$ \\
\hline & \multicolumn{3}{|c|}{ Appearance (10) } \\
\hline $\mathbf{T}_{1}$ & $7^{b}$ & $6^{c}$ & $5^{d}$ \\
\hline $\mathbf{T}_{\mathbf{2}}$ & $7^{b}$ & $7^{b}$ & $5^{d}$ \\
\hline $\mathbf{T}_{3}$ & $7^{b}$ & $7^{b}$ & $6^{c}$ \\
\hline $\mathbf{T}_{\mathbf{4}}$ & $7^{b}$ & $7^{b}$ & $6^{c}$ \\
\hline \multirow[t]{2}{*}{$T_{5}$} & $8^{\mathrm{a}}$ & $8^{a}$ & $7^{b}$ \\
\hline & \multicolumn{3}{|c|}{ Consistency (30) } \\
\hline $\mathbf{T}_{1}$ & $20^{d}$ & $17^{d}$ & $14^{\mathrm{d}}$ \\
\hline $\mathbf{T}_{\mathbf{2}}$ & $22^{\mathrm{c}}$ & $20^{c}$ & $17^{c}$ \\
\hline $\mathbf{T}_{3}$ & $25^{\mathrm{b}}$ & $23^{b}$ & $20^{b}$ \\
\hline $\mathbf{T}_{\mathbf{4}}$ & $26^{\mathrm{a}}$ & $24^{\mathrm{b}}$ & $21^{\mathrm{b}}$ \\
\hline \multirow[t]{2}{*}{$T_{5}$} & $27^{\mathrm{a}}$ & $26^{\mathrm{a}}$ & $25^{\mathrm{a}}$ \\
\hline & \multicolumn{3}{|c|}{ Flavour (50) } \\
\hline$T_{1}$ & $30^{c}$ & $28^{\mathrm{d}}$ & $20^{c}$ \\
\hline $\mathbf{T}_{2}$ & $35^{b}$ & $33^{c}$ & $26^{\mathrm{b}}$ \\
\hline $\mathbf{T}_{3}$ & $38^{\mathrm{a}}$ & $37^{b}$ & $27^{b}$ \\
\hline $\mathbf{T}_{4}$ & $38^{a}$ & $37^{b}$ & $27^{b}$ \\
\hline \multirow[t]{2}{*}{$T_{5}$} & $39^{a}$ & $39^{a}$ & $33^{\mathrm{a}}$ \\
\hline & \multicolumn{3}{|c|}{ Total score (100) } \\
\hline $\mathbf{T}_{1}$ & $65^{c}$ & $58^{d}$ & $44^{d}$ \\
\hline $\mathbf{T}_{2}$ & $72^{\mathrm{bc}}$ & $68^{c}$ & $55^{c}$ \\
\hline$T_{3}$ & $78^{\mathrm{b}}$ & $75^{\mathrm{bc}}$ & $60^{\mathrm{b}}$ \\
\hline $\mathbf{T}_{4}$ & $80^{\mathrm{ab}}$ & $77^{b}$ & $62^{b}$ \\
\hline$T_{5}$ & $83^{a}$ & $82^{\mathrm{a}}$ & $73^{\mathrm{a}}$ \\
\hline
\end{tabular}

$a, b, \ldots . .$. etc means with different superscripts in the same row or column within different significantly $(P<0.05)$.

\section{CONCLUSION}

From the obtained results, it could be concluded that permeate which was produced by ultrafiltration for milk can be mixed with skim milk powder, a single strain of Bifidobacterium bifidum, strawberry pulp and 3 or $4 \%$ of chikpea to produce a cheap acceptable fermented milk drink. On the other hand,the presence of Bifidobacteria during production of Probiotic fermented milk drink from permeate could be considered as an alternative probiotic dairy product and as a good source of vitamin $\mathrm{C}$, essential amino acids, calcium and phosphorus. 


\section{REFERENCES}

1. Abd El-Khair, A.A. 2009. Formulation of milk permeates for utilization as electrolyte beverages. Australian J. Basic and Applied Sci., 3 (2), pp. 572-578.

2. Abd El-Salam,M.H.,Hareedy,L.A.M. and El-Bialy, A.R. 2007. Production a new functional beverages from fermented whey and fermented Permeate and tomato syrup proceeding of the 10th Egyptian Conference for Dairy Science and Tecnologynology,19-21,November 2007, 301.Cairo-Egypt.

3. Allen, R.J.L. 1940. The estimation of phosphorus, Biochem. J. 34: 858.

4. A.O.A.C. 2002. Official methods of analysis association of official Agriculture Chemist Washington.

5. Aumara, I.E. and Hassan, Z.M.R. 2007. More healthy fermented milk manufactured with Doum palm fruit powder. Proceeding of the 10th Egyptian Conference for Dairy Science and Technology, 19-21, November 2007, 283-300. Cairo Egypt.

6. Bernett, A.J.G. and Abdel-Tawab, G. 1957. A rapid method for the determination of lactose in milk and cheese. J. Food Sci. Agric. 8: 437: 441.

7. Block, R.J., Durrum, E.L. and Zweig, G. 1958. Annual of paper chromatography and paper electrophoresis 2nd ed., Academic Press, New Fork P.75-80.

8. Codex Standard for fermented milks, Codex standard 243-2003. Revision. 2008.

9. Coakley, D., Grubb, R., Paradiso, M., Gatzy, T.,Jonson, G., Kreda, M., O'Neal, K. and Boucher, $\mathrm{C}, 2003$. Abnormal surface liquid $\mathrm{pH}$ regulation by cultured cystic fibrsis bronchial epithelium. The National Academy of Sciences.

10. Dave, R.I. and Shah, N.P. (1996). Evaluation of media for selective enumeration of Streptococcus thermophilus, Lactobacillus delbrueckii spp. bugaricus, Lactobacillus acidophilus and bifidobacteria. J. Dairy Sci., 79: 1529.

11. Davidson, R.H., Duncan, S.E., Hackney, C.R., Eigel, W.N., Boling, J.W. (2000). Probiotic culture survival and implication in fermented frozen yogurt characteristics, J. Dairy Sci., 83, 666-673.

12. Duncan, D.B. (1955). Multiple ranged multiple F. Test Biometrics, 11: 1-42.

13. Farag, S.I., Khader, A.E., Mousa, A.M. and El-Batawy, A.M. (1993). A study on ice cream 1-on the use of high fructose corn syrup as a sweetener. Egyptian J.Dairy Sci.21:97.

14. Folkenberg, D.M., Dejmek, P., 3kriver, A., Guldager, H.Z. and Ipsen, R. 2006. Sensory and rheological screening of exopolysaccharide producing strains of bacterial yoghurt cultures. Int. Dairy J., 16: 111. 
15. Hegazi, N.A., AboelEinen, K.A.M. and El-Nawawy, M.A. 2009. Production of low calories highly antioxidant thirst quenching fruit beverage using milkpermeate. J. Biol Sci.4: 857-868.

16. Katsanos, C.S., Kobayashi, H., Sheffield-Moore, M., Aersland, A., Wolfel R.R. 2006. A high proportion of leucine is required for optimal stimulation of the rate muscle protein synthesis by essential amino acids in the elderly. American Journal of Physiology Endocrinology and Metabolism 291, E381.

17. National Food Agency of Denmark Ministry of Health, Institute Food Chemistry and Nutritional/Danish Official (1996).

18. Tonguc, I.E. 2012. Developing fermented dairy products with low galactose content for palients with galactosemia and lactose intolerance and determination of quality characteristics,(Ph.D.Thesis), Ege University, Department of Dairy Technology, 163 pages, (2012).

19. Ventling, B.L. and Mistry .V .V. 1993. Growth characteristics of bifidobacteria in ultrafiltered milk J. Dairy Sci. 76: 962.

20. Zare, F., Boye , J.I., Orsat, V. \& Simpson, B.K. 2009. Development of food products supplemented with pulse ingredients. IFT, June 6th 10th, Anaheim, CA, USA, (Poster presentation). 


\section{استخدام منتجات الالبان الثانوية في اعداد مشروب لبني

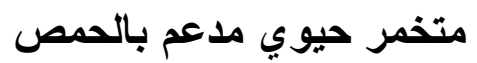

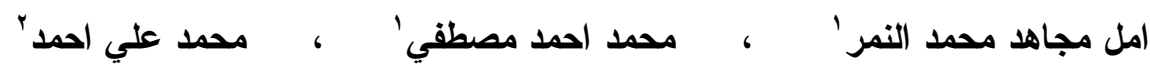
ا ـ قسم بحوث تكنولوجيا الالبان - معهر بحوث الانتاج الحيواني - مركزالبحوث الزراعية - الدقي

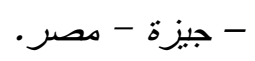

r. قسم بحوث تكنولوجيا الالبان - محطة سدس - معهُ بحوث الانتاج الحبواني - مركز البحوث

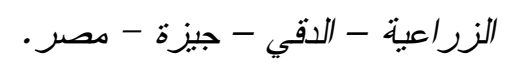

يهدف هذا البحث إلى محاولة إنتاج مشروب لبن متخمر باستخدام البرمييت (منتج لبنى

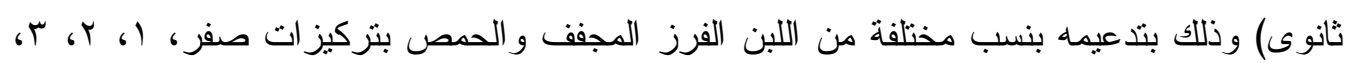

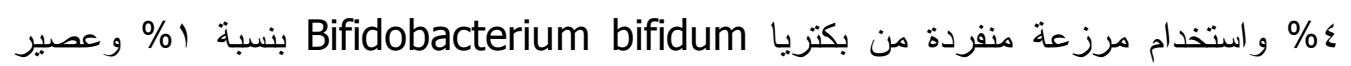

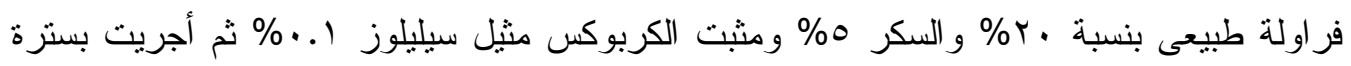

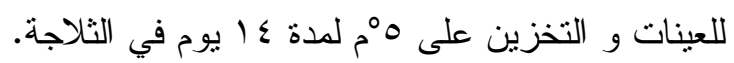

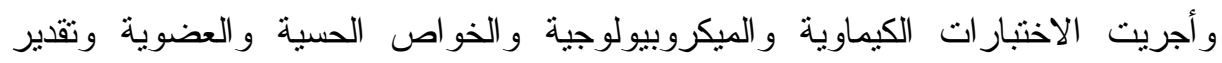

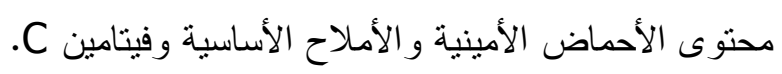

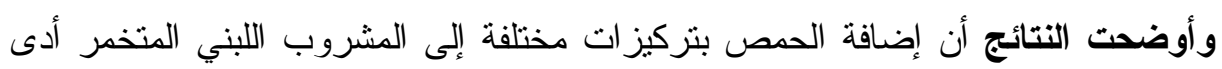

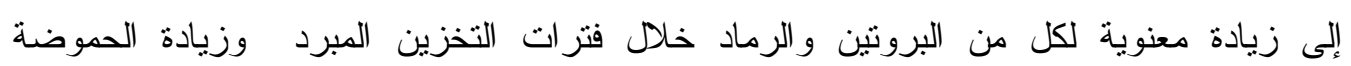

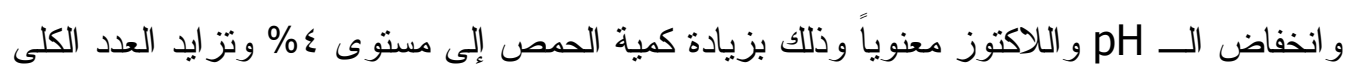

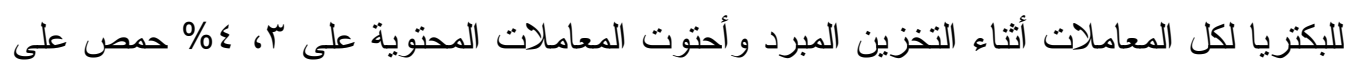

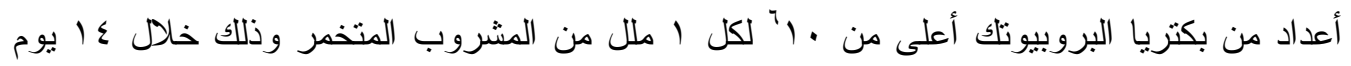

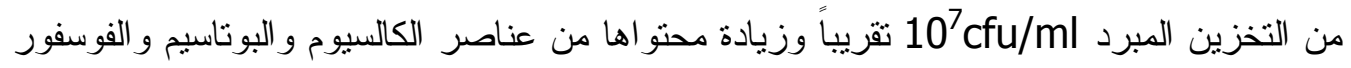

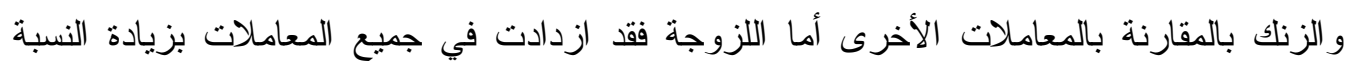

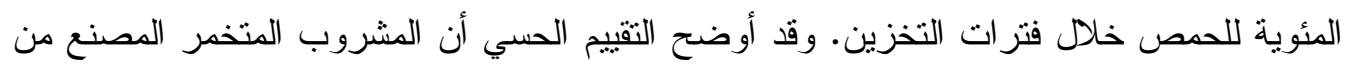
90\% برمييت: 1\% لبن فرز مجفف: ؛ ٪ حمص حصل على أفضل قبول، وقد ساهم وجود بكتريا

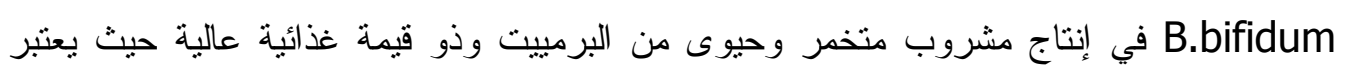
مصدر جيد لفيتامين C والأحماض الأمينية الأساسية والأملاح المعدنية الأساسية من الكالسيوم و الفو سفور • مئن 